\title{
PENGGUNAAN MEDIA POWTOON UNTUK MENINGKATKAN MINAT DAN HASIL BELAJAR SISWA PADA KOMPETENSI DASAR MENDESKRIPSIKAN PELAKU-PELAKU EKONOMI DALAM SISTEM PEREKONOMIAN INDONESIA (Studi Kasus Pada Siswa Kelas VIIID SMP Nurul Islam Jember Semester Genap Tahun Pelajaran 2017/2018)
}

\author{
Rio Ariyanto ${ }^{1}$, Sri Kantun ${ }^{1}$, Sukidin ${ }^{1}$ \\ ${ }^{1}$ Program Studi Pendidikan Ekonomi, Fakultas Keguruan dan Ilmu Pendidikan, Universitas Jember \\ e-mail: rio.ariyanto21@gmail.com
}

\begin{abstract}
Abstrak
Penelitian ini bertujuan untuk: mendeskripsikan penggunaan media powtoon untuk meningkatkan minat dan hasil belajar pada siswa kompetensi dasar mendeskripsikan pelaku-pelaku ekonomi dalam sistem perekonomian Indonesia semester genap tahun pelajaran 2017/2018, untuk meningkatkan minat dan hasil belajar siswa melalui penggunaan media powtoon. Penelitian ini merupakan penelitian tindakan kelas (PTK) yang terdiri atas dua siklus. Setiap siklus terdiri atas tahap perencanaan, pelaksanaan tindakan, pengamatan (observasi) dan refleksi. Subyek penelitian ini adalah seluruh siswa kelas VIIID yang berjumlah 35 siswa. Teknik pengumpulan data meliputi observasi, wawancara, tes, dan dokumen. Teknik analisis data menggunakan analisis deskriptif kualitatif. Hasil penelitian menunjukkan bahwa: Minat belajar siswa pada siklus I sebesar 2,9 dengan kriteria sedang, meningkat menjadi 3,2 dengan kriteria tinggi pada siklus II. Sedangkan rata-rata nilai hasil belajar siswa pada siklus I sebesar 77,28 dengan ketuntasan klasikal sebesar 60\%, meningkatkan menjadi 81,42 dengan ketuntasan klasikal 85,71\% pada siklus II. Penggunaan media powtoon dapat meningkatkan minat dan hasil belajar siswa kelas VIIID SMP Nurul Islam Jember pada kompetensi dasar mendeskripsikan pelaku-pelaku ekonomi dalam sistem perekonomian Indonesia semester genap tahun pelajaran 2017/2018.
\end{abstract}

Kata Kunci: Media Pembelajaran Powtoon, Minat Belajar, Hasil

\section{PENDAHULUAN}

Salah satu bidang keilmuan yang penting dalam bidang kehidupan adalah Ekonomi. Ekonomi merupakan bidang kajian yang mempelajari tentang aktivitas manusia dalam memenuhi kebutuhannya yang tidak terbatas dan selalu berkembang. Pelajaran ekonomi di SMP merupakan mata pelajaran yang wajib ditempuh oleh semua siswa seluruhnya. Tujuan diajarkan ekonomi di SMP yaitu untuk membekali siswa agar mampu memahami konsep dasar ekonomi sebagai pedoman dalam berperilaku secara ekonomi, sehingga siswa mampu memecahkan permasalahan dan peristiwa yang terjadi dalam kehidupan sehari-hari. Kegiatan pembelajaran ekonomi di kelas berisi proses komunikasi yang dilakukan oleh guru dan siswa, dimana guru yang menentukan arah komunikasi yang terjadi. Guru terlebih dahulu merancang rencana pelaksanaan pembelajaran (RPP), mementukan dan membuat media yang akan digunakan, menentukan metode pembelajaran yang sesuai dengan materi ajar dan lainnya. Penelitian dilakukan di SMP Nurul Islam karena peneliti melihat adanya permasalahan yang dihadapi oleh guru mata pelajaran IPS di kelas VIII. Berdasarkan hal tersebut dan adanya dukungan dari pihak sekolah untuk menerima peneliti melakukan penelitian serta adanya kemauan guru untuk mengatasi permasalahan pembelajaran dengan melakukan perbaikan, maka di harapkan permasalahan tersebut dapat teratasi. Berdasarkan hasil wawancara dengan guru mata pelajaran IPS kelas VIII, guru merekomendasikan untuk melakukan perbaikan di kelas VIIID. Hal ini disebabkan karena menurut guru kelas VIIID memiliki minat dan hasil belajar siswa yang rendah.

Hasil observasi awal menunjukkan minat belajar siswa di kelas VIIID paling rendah dari kelas lainnya, yaitu dengan skor rata-rata minat belajar mencapai 2,45 (rendah). Skor rata-rata minat belajar siswa dapat diukur dari rasa suka, partisipasi, perhatian dan ketekunan siswa selama pembelajaran berlangsung. Dari hasil wawancara dengan guru mata pelajaran IPS kelas VIII, permasalahan di kelas VIIID ini disebabkan oleh beberapa faktor antara lain guru masih memakai media pembelajaran yang biasa, yaitu power point. Power point yang digunakan kurang menarik karena hanya menampilkan materi saja sehingga siswa kurang aktif dalam pembelajaran di kelas. Guru perlu menggunakan media pembelajaran yang dapat meningkatkan minat belajar siswa dalam proses belajar di kelas VIIID. Media pembelajaran yang tepat untuk mengatasi permasalahan tersebut adalah media pembelajaran Powtoon. Dengan menggunakan media Powtoon diharapkan minat dan 
hasil belajar siswa bisa meningkat. Powtoon merupakan program aplikasi yang bersifat online yang ada di internet dan berfungsi sebagai aplikasi pembuat video untuk presentasi maupun media pembelajaran. Peneliti menggunakan media Powtoon tersebut untuk diterapkan di SMP Nurul Islam Jember sebagai media pembelajaran untuk lebih menarik minat siswa dalam pembelajaran khususnya pada siswa-siswi kelas VIII. Media ini akan menumbuhkan ketertarikan siswa, menumbuhkan minat belajar siswa dan menumbuhkan hasil belajar siswa.

Ada penelitian yang sejenis yang dijadikan acuan bagi peneliti untuk melakuakan penelitian ini. Penelitian yang dilakukan peneliti sebelumnya oleh Khamid Faujan Zumroni (2015) dengan judul "Penggunaan Media Powtoon dalam Pembelajaran Sejarah untuk Meningkatkan Hasil Belajar Siswa Kelas X IPS 1 SMA Negeri 1 Slahung Ponorogo" dan Penelitian sejenis selanjutnya dilakukan oleh Maria Virginingsih (2011) dengan judul "Penggunaan Media Audio Visual Untuk Meningkatkan Minat dan Hasil Belajar Siswa".

Media pembelajaran Powtoon merupakan salah satu media pembelajaran berbasis audio dan visual. Menurut Mafita Sari \& Suci Rohayati (2017:1) "Powtoon merupakan salah satu jenis layanan online yang memiliki fitur animasi yang menarik dalam penyampaian pesan berupa video. Ini adalah salah satu alternatif dari berkembangnya teknologi untuk digunakan media pembelajaran interaktif pada materi yang dianggap sulit menjadi lebih menyenangkan karena disajikan dengan kombinasi beberapa media seperti audio dan visual. Oleh karena itu media ini sangatlah menarik untuk digunakan di dalam kelas sebagai alternatif media pembelajaran agar siswa tidak bosan dengan pembelajaran selain itu juga membuat media pembelajaran guru lebih bervariatif".

Minat belajar siswa dapat dilihat dari kegiatan yang dilakukan siswa pada saat pelajaran berlangsung, karena kegiatan mereka merupakan kunci dari minat mereka. Menurut Nasution (2000:46) bahwa "Minat belajar terhadap pelajaran akan tampak pada ketekunan dalam belajar. Minat berperan penting bagi peserta didik karena minat belajar berpengaruh terhadap keberhasilan belajar siswa". Pengertian minat belajar menurut Slameto (2003:180) minat merupakan suatu rasa lebih suka dari ketertarikan pada aktifitas, tanpa ada yang menyuruh. Siswa yang memiliki minat belajar terhadap sesuatu akan terlihat dari tingkah lakunya.

Menurut Jihad dkk (2012:14), hasil belajar adalah pencapaian bentuk perubahan tingkah laku siswa secara nyata setelah dilakukan proses belajar mengajar yang sesuai dengan tujuan pengajaran yang cenderung menetap dari ranah kognitif, afektif dan psikomotor. Setelah melalui proses belajar maka siswa diharapkan dapat mencapai tujuan belajar yang disebut juga sebagai hasil belajar. Tujuan belajar adalah sejumlah hasil belajar yang menunjukkan bahwa siswa telah melakukan perbuatan belajar, pengetahuan, keterampilan dan sikap-sikap yang baru, yang diharapkan dapat dicapai oleh siswa.

Peranan penggunaan media pembelajaran Powtoon dapat membuat siswa lebih memahami pelajaran dan membangkitkan semangat belajar. Dengan suasana pembelajaran yang menarik perhatian, maka siswa dapat mempengaruhi minat belajar siswa sehingga dapat meningkatkan hasil belajar siswa.

Berdasarkan penelitian di atas, maka hipotesis dalam penelitian ini adalah penggunaan media pembelajaran Powtoon dapat meningkatkan minat belajar siswa dan penggunaan media pembelajaran Powtoon dapat meningkatkan hasil belajar siswa.

\section{METODE}

Penelitian ini merupakan penelitian tindakan kelas (PTK) yang dilaksanakan di SMP Nurul Islam jember sebanyak dua siklus. Subyek penelitian ini adalah seluruh siswa kelas VIIID sebanyak 35 siswa. Teknik pengumpulan data dalam penelitian ini menggunakan metode observasi, wawancara, tes, dan dokumen. Metode analisis data menggunakan analisis deskriptif kualitatif. Prosedur penelitian tindakan kelas ini setiap siklusnya terdiri atas empat kegiatan yaitu: 1) Perencanaan, sebelum mengadakan penelitian peneliti menyusun rumusan masalah, tujuan dan membuat rencana tindakan, termasuk di dalamnya intrumen penelitian dan perangkat pembelajaran. 2) Tindakan dan pengamatan atau observasi, meliputi tindakan yang dilakukan oleh peneliti sebagai upaya membangun pemahaman konsep peserta didik serta mengamati hasil atau dampak dari penggunaan media pembelajaran Powtoon. 3) Refleksi, Tahap refleksi diperlukan untuk mengkaji serangkaian kegiatan yang telah dilakukan sebelumnya. Pengkajian kembali dapat digunakan peneliti untuk mengetahui kegiatan yang telah dicapai dan yang belum dicapai pada saat pelaksanaan tindakan dan observasi. 4) Rencana perbaikan, Kegiatan yang dilaksanakan pada tahap perencanaan pada siklus II, berdasarkan refleksi dari siklus I, diperoleh data mengenai kekurangan-kekurangan yang terjadi pada siklus I yang merupakan acuan untuk melaksanakan tindakan perbaikan pada siklus II agar hasil tindakan yang dicapai lebih optimal. 


\section{HASIL DAN PEMBAHASAN Hasil Penelitian}

Penelitian ini dilaksanakan sebanyak dua siklus, setiap siklus terdiri dari dua pertemuan. Pada siklus I guru sudah menggunakan media Powtoon dengan baik meskipun masih ada beberapa kendala yang disebabkan karena media Powtoon merupakan media yang masih baru pertama kali digunakan di kelas VIIID. Kendala yang dihadapi pada siklus I dapat diperbaiki pada siklus II, sehingga pada siklus II pembelajaran dengan menggunakan media pembelajaran Powtoon berjalan dengan lancar dan sesuai perencanaan yang sudah dibuat pada RPP.

Adapun skor minat belajar siswa pada siklus I dan siklus II terlihat dalam tabel 1 berikut.

Tabel 1. Rata-rata Minat Belajar Siswa Kelas VIIID SMP Nurul Islam Jember

\begin{tabular}{|c|l|c|c|c|c|}
\hline No. & \multicolumn{1}{|c|}{ Indikator Minat Belajar Siswa } & Siklus I & Kriteria & $\begin{array}{c}\text { Siklus } \\
\text { II }\end{array}$ & Kriteria \\
\hline 1. & Rasa suka siswa terhadap pelajaran & 3,6 & Tinggi & 3,6 & Tinggi \\
\hline 2. & $\begin{array}{l}\text { Partisipasi siswa dalam proses belajar } \\
\text { mengajar }\end{array}$ & 2,22 & Rendah & 2,5 & Sedang \\
\hline 3. & $\begin{array}{l}\text { Perhatian siswa selama proses belajar } \\
\text { mengajar }\end{array}$ & 3,4 & Tinggi & 3,4 & Tinggi \\
\hline 4. & Ketekunan belajar siswa & 2,25 & Rendah & 3,1 & Tinggi \\
\hline & Jumlah skor rata-rata & 2,9 & Sedang & 3,2 & Tinggi \\
\hline
\end{tabular}

Sumber:Data primer yang diolah 2018

Tabel 1 diatas menunjukkan bahwa skor rata-rata minat belajar siswa mengalami peningkatan. Pada siklus I skor rata-rata minat belajar siswa sebesar 2,9 dengan kriteria sedang, meningkat pada siklus II menjadi 3,2 dengan kriteria tinggi. Indikator Rasa suka terhadap pelajaran dan perhatian siswa selama proses belajar mengajar baik pada siklus I maupun siklus II sudah berada pada kriteria tinggi. Sedangkan indikator partisipasi siswa dalam proses belajar mengajar meningkat dari siklus I rendah meningkat menjadi sedang pada siklus II dan ketekunan belajar siswa pada kriteria rendah pada siklus I dan meningkat pada siklus II menjadi tinggi. Peningkatan minat belajar siswa diatas, dapat dilihat pada gambar diagram berikut.

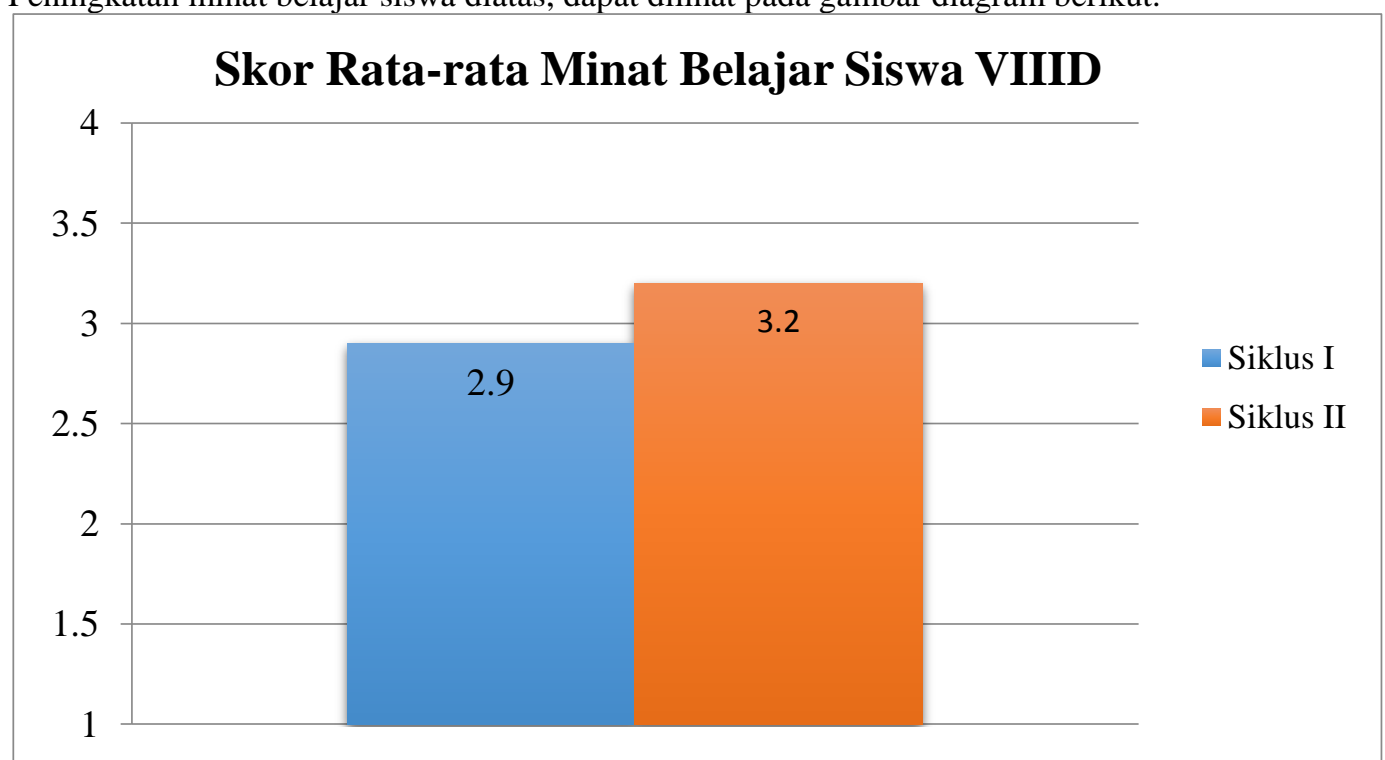

Gambar 1. Diagram peningkatan minat belajar siswa Siklus I dan Siklus II

Sumber: Data primer yang diolah 2018

Gambar di atas menunjukkan bahwa adanya peningkatan skor rata-rata minat belajar siswa dari siklus I sampai siklus II. Peningkatan skor rata-rata minat belajar pada siklus II menunjukkan skor 3,2 dengan kriteria tinggi. Hal tersebut ditunjukkan dengan rasa suka siswa memperhatikan penjelasan guru dan perhatian siswa selama mengikuti pembelajaran dengan media Powtoon dengan baik.

Peningkatan minat belajar diatas, ternyata juga diikuti dengan peningkatan hasil belajar siswa. Setelah dilakukan tes atau ulangan harian yang diadakan setiap akhir siklus, maka dapat dilihat rata-rata hasil belajar siswa seperti yang tampak pada tabel berikut:

Tabel 2 Rekapitulasi Hasil Belajar Siswa siklus I dan siklus II 


\begin{tabular}{|c|c|c|c|c|c|c|c|c|c|c|c|}
\hline $\begin{array}{c}\text { Jum. } \\
\text { Siswa }\end{array}$ & \multicolumn{2}{|c|}{ Nilai Rata-rata } & \multirow{2}{*}{$\begin{array}{c}\text { Peni } \\
\text { ng } \\
\text { Kat } \\
\text { an }\end{array}$} & \multicolumn{2}{|c|}{$\begin{array}{c}\text { Jum siswa } \\
\text { tuntas }\end{array}$} & \multicolumn{2}{|c|}{$\begin{array}{l}\text { Jum siswa } \\
\text { tidak tuntas }\end{array}$} & \multicolumn{2}{|c|}{$\begin{array}{c}\text { Ketuntasan } \\
\text { Klasikal }\end{array}$} & \multirow{2}{*}{$\begin{array}{l}\text { Pening } \\
\text { Katan }\end{array}$} & \multirow{2}{*}{ Ket } \\
\hline \multirow{2}{*}{35} & Sik. I & $\begin{array}{l}\text { Sik. } \\
\text { II }\end{array}$ & & $\begin{array}{c}\text { Sik. } \\
\text { I }\end{array}$ & $\begin{array}{l}\text { Sik. } \\
\text { II }\end{array}$ & Sik.I & Sik.II & Sik.I & Sik.II & & \\
\hline & 77,28 & 81,42 & 4,14 & 21 & 30 & 14 & 5 & $60 \%$ & $85,71 \%$ & $25,71 \%$ & Tuntas \\
\hline
\end{tabular}

Sumber: Data primer yang diolah 2018

Tabel 2 diatas menunjukkan bahwa hasil belajar dari siklus I sampai siklus II mengalami peningkatan. Pada siklus I nilai rata-rata siswa sebesar 77,28 dengan ketuntasan klasikal 60\%, pada siklus II nilai rata-ratanya naik menjadi 81,42 dengan ketuntasan klasikal $85,71 \%$. Tabel peningkatan hasil belajar diatas dapat digambarkan dalam diagram berikut.

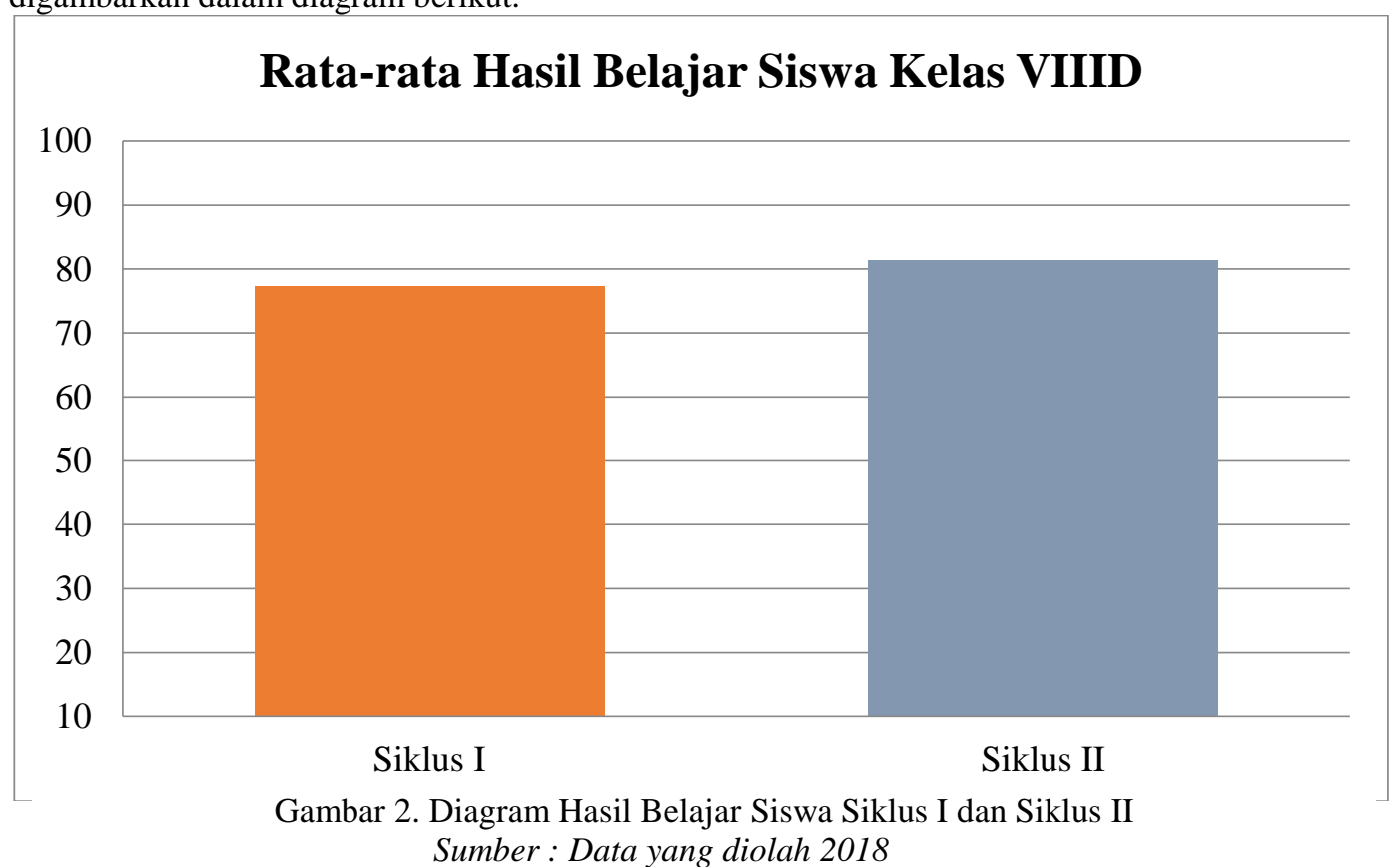

Berdasarkan gambar diagram analisis hasil belajar siswa diatas, dapat diketahui peningkatan hasil belajar siswa setelah dilakukan tindakan perbaikan dengan penggunaan media pembelajarn Powtoon pada kompetensi dasar mendeskripsikan pelaku-pelaku ekonomi dalam sistem perekonomian Indonesia. Nilai rata-rata hasil belajar pada siklus I sebesar 77,28 dengan ketuntasan klasikal 60\% meningkat menjadi 81,42 dengan ketuntasan klasikal sebesar $85,71 \%$ pada siklus II. Peningkatan hasil belajar tersebut menunjukkan bahwa target penelitian telah tercapai yaitu siswa yang mendapatkan nilai lebih dari KKM yang ditentukan sekolah yaitu >70 lebih dari $75 \%$ dari seluruh siswa kelas VIIID.

\section{Pembahasan}

Hasil penelitian menunjukkan bahwa penggunaan media pembelajaran Powtoon dapat meningkatkan minat belajar dan hasil belajar siswa pada pelajaran IPS materi pelaku-pelaku ekonomi dalam sistem perekonomian Indonesia siswa kelas VIIID SMP Nurul Islam Jember tahun ajaran 2017/2018. Dimana minat belajar siswa meningkat dari kategori sedang menjadi tinggi. Hasil belajar siswa pada siklus 2 menunjukkan peningkatan hasil belajar dari 77,28 menjadi 81,42. Sehingga dapat disimpulkan bahwa hasil belajar siswa kelas VIIID telah mencapai ketuntasan KKM sekolah yaitu 70. Hal ini membuktikan bahwa hipotesis yang diajukan dalam penelitian ini terbukti.

Peningkatan minat belajar siswa dapat dilihat pada proses pembelajaran menggunakan media pembelajaran Powtoon, siswa memanfaatkan waktu yang diberikan guru untuk kegiatan perhatian siswa yang terbukti dengan siswa dapat memahami materi yang diterangkan oleh guru dengan menggunakan media Powtoon, selanjutnya siswa memasukkan kata kunci materi pelajaran yang mereka temukan dalam media Powtoon sebagai catatan materi. Siswa memperhatikan media dan rasa suka siswa terhadap pelajaran, serta siswa dapat memahami dan mengerti pelajaran lebih baik. Sehingga muncul minat partisipasi siswa dalam bertanya dan menjawab meskipun tidak semua siswa bertanya, hanya sebagian kecil siswa yang berpartisipasi. 
Hal ini disebabkan karena siswa telah memahami materi yang dijelaskan oleh guru, sehingga siswa tidak perlu bertanya untuk memperjelas materi pelajaran.

Peningkatan minat belajar dan hasil belajar siswa juga diakui oleh guru IPS kelas VIIID sebagai pelaksana dari kegiatan perbaikan pembelajaran, berdasarkan hasil wawancara dengan guru yang menyatakan:

"Saya tidak menyangka anak-anak bisa berubah, biasanya ulangan harian siswa 50, 60 dan dapat 75 udah bagus, sekarang anak-anak banyak yang dapat nilai 75,80 Saya senang sekali. Jujur saya merasa mudah dan simpel saat mengajar dengan menggunakan media Powtoon ini yang baru saya ketahui. Saya ingin menggunakan media Powtoon ini untuk mengajar pada kelas lainnya dan pada pelajaran lainnya. Saya menilai minat belajar siswa dapat dikatakan aktif meskipun tidak semua siswa." (Bapak Subhan, 28 tahun)

Berdasarkan pernyataan guru diatas media Powtoon mempermudah guru dalam pembelajaran siswa. Menurut Arsyad (2016:89), penggunaan media audio visual memegang peran yang sangat penting dalam proses belajar. Audio visual dapat pula menumbuhkan minat siswa dan dapat memberikan hubungan antara isi materi pelajaran dengan dunia nyata.

Peningkatan minat belajar dan hasil belajar siswa, juga dirasakan langsung oleh siswa berdasarkan hasil wawancara kepada siswa yang memiliki hasil belajar tertinggi yaitu:

"iya kak, saya bersemangat, suka dan memperhatikan ketika guru menggunakan media Powtoon sebagai media pembelajaran di kelas saya. Karena media ini merupakan media yang baru bagi kami dari sebelumnya guru cuma menggunakan power point. Jadi ini membuat saya dan teman-teman memperhatikan guru mengajar." (Siswa L, 14 tahun).

Peningkatan hasil belajar siswa melalui penggunaan media pembelajaran Powtoon yang dialami oleh siswa kelas VIIID yang memiliki hasil belajar jauh dari ketuntasan kelas hingga mencapai nilai ketuntasan kelas sebesar 86\% merupakan bukti bahwa pendapat Mayer dan Moreno (2002:20) yang menyatakan, dengan penggunaan media animasi dalam proses pembelajaran sangat membantu dalam meningkatkan efektifitas dan efesiensi proses pengajaran, serta hasil pembelajaran meningkat.

Berdasarkan hasil penelitian tindakan ini membuktikan bahwa hasil penelitian ini telah menjawab hipotesis tindakan yaitu penggunaan media pembelajaran Powtoon dapat meningkatkan minat belajar dan hasil belajar siswa kelas VIIID SMP Nurul Islam Jember pada kompetensi dasar mendeskripsikan pelaku-pelkau ekonomi dalam sistem perekonomian Indonesia semester genap tahun pelajaran 2017/2018. Akhirnya, dengan tercapainya tujuan penelitian dan terbuktinya hipotesis tindakan, maka penelitian ini dinyatakan berhasil.

\section{PENUTUP}

Berdasarkan hasil penelitian dan pembahasan, dapat disimpulkan bahwa penggunaan media Powtoon dapat meningkatkan minat dan hasil belajar siswa pada kompetensi dasar mendeskripsikan pelaku-pelaku ekonomi dalam sistem perekonomian Indonesia kelas VIIID SMP Nurul Islam Jember semester genap tahun pelajaran 2017/2018. Peningkatan minat belajar siswa dapat dilihat dari skor rata-rata minat sebelum tindakan yaitu 2,45 dengan kriteria rendah, pada siklus I mengalami peningkatan menjadi 2,9 dengan kriteria sedang, dan pada siklus II mengalami peningkatan kembali menjadi 3,2 dengan kriteria tinggi. Peningkatan hasil belajar siswa dapat dilihat dari rata-rata nilai ulangan harian siswa sebelum tindakan yaitu 72. Pada siklus I mengalami peningkatan rata-rata nilai ulangan harian menjadi 77,28. Kemudian mengalami peningkatan kembali pada siklus II dengan nilai rata-rata ulangan harian siswa menjadi 81,42. Peningkatan minat dan hasil belajar siswa pada kompetensi dasar mendeskripsikan pelaku-pelaku ekonomi dalam sistem perekonomian Indonesia siswa kelas VIIID SMP Nurul Islam Jember ini menunjukkan tercapainya tujuan penelitian penggunaan media Powtoon.

\section{DAFTAR PUSTAKA}

Arsyad, Azhar. 2016. Media Pembelajaran. Jakarta: PT Rajagrafindo Persada

Jihad dkk. 2012. Evaluasi pembelajaran. Yogyakarta: Multi Presindo.

Nasution, N. 2000. Didaktik Asas-Asas Mengajar. Jakarta: PT. Rineka Cipta

Slameto. 2003. Belajar Dan Faktor-Faktor Yang Mempengaruhinya. Jakarta: PT Rineka Cipta

Khamid. 2015. Penggunaan Media Powtoon Dalam Pembelajaran Sejarah Untuk Meningkatkan Hasil Belajar Siswa Kelas X IPS 1 SMA Negeri 1 Slahung Ponorogo. Skripsi. Universitas Malang, Jawa Timur. Tidak dipublikasikan 
Maria. 2011. Penggunan Media Audio Visual Untuk Meningkatkan Minat Belajar Dan Hasil Belajar Siswa Kelas VIII F SMP Negeri 2 Balung Jember. Skripsi. Universitas Jember, Jawa Timur. Tidak dipublikasikan

Mayer \& Moreno (2002) Animation as an aid Multimedia learning, educational psychology review, Vol. 14, No.1, March 2002. Diakses dari http://search.proquest.com pada tanggal 08 Mei 2018 